\title{
Integrated Genomic Analysis of Sézary Syndrome
}

\author{
Xin Mao, ${ }^{1,2}$ Tracy Chaplin, ${ }^{3}$ and Bryan D. Young ${ }^{3}$ \\ ${ }^{1}$ Centre for Cutaneous Research, Institute of Cell and Molecular Sciences, Barts and The London School of \\ Medicine and Dentistry, London E1 2AT, UK \\ ${ }^{2}$ Division of Investigative Science, Department of Histopathology, Faculty of Medicine, Imperial College, Hammersmith Hospital, \\ Du cane Road, London W12 ONN, UK \\ ${ }^{3}$ Cancer Research UK Medical Oncology Centre, Barts and The London School of Medicine and Dentistry, Queen Mary College, \\ Queen Mary University of London, London EC1M 6BQ, UK
}

Correspondence should be addressed to Xin Mao, mxmayo@yahoo.co.uk

Received 16 April 2011; Revised 7 August 2011; Accepted 29 August 2011

Academic Editor: Ilana Zalcberg Renault

Copyright $\odot 2011$ Xin Mao et al. This is an open access article distributed under the Creative Commons Attribution License, which permits unrestricted use, distribution, and reproduction in any medium, provided the original work is properly cited.

\begin{abstract}
Sézary syndrome (SS) is a rare variant of primary cutaneous T-cell lymphoma. Little is known about the underlying pathogenesis of S. To address this issue, we used Affymetrix 10K SNP microarray to analyse 13 DNA samples isolated from 8 SS patients and qPCR with ABI TaqMan SNP genotyping assays for the validation of the SNP microarray results. In addition, we tested the impact of SNP loss of heterozygosity (LOH) identified in SS cases on the gene expression profiles of SS cases detected with Affymetrix GeneChip U133A. The results showed: (1) frequent SNP copy number change and LOH involving 1, 2p, 3, 4q, 5q, 6, 7p, 8, 9, 10, $11,12 q, 13,14,16 q, 17$, and 20, (2) reduced SNP copy number at FAT gene (4q35) in 75\% of SS cases, and (3) the separation of all SS cases from normal control samples by SNP LOH gene clusters at chromosome regions of 9q31q34, 10p11q26, and 13q11q12. These findings provide some intriguing information for our current understanding of the molecular pathogenesis of this tumour and suggest the possibility of presence of functional SNP LOH in SS tumour cells.
\end{abstract}

\section{Introduction}

Sézary syndrome (SS) is a rare subset of primary cutaneous T-cell lymphoma (CTCL) with an aggressive clinical course $[1,2]$. SS typically presents with generalised skin lesions or erythroderma, intense pruritus, and peripheral lymphadenopathy. A blood test will reveal atypical T-lymphocytes with convoluted nuclei, Sézary cells, which are often associated with a cutaneous T-cell lymphoma [2-5]. Recent studies have revealed complex genetic aberrations affecting almost all chromosomes [6-14] with loss of heterozygosity (LOH), [9, 15-19] and deregulation of several genes, [20-26] and epigenetic changes $[27,28]$ in SS. Despite this progress, the key molecular targets underlying the pathogenesis of this type of skin lymphoma remain elusive.

Single nucleotide polymorphism (SNP) denotes a single base in the DNA sequence that differs from the usual base at that position. Millions of SNPs have been catalogued in the human genome, which may be responsible for disease such as cancer (http://www.ncbi.nlm.nih.gov/sites/entrez?db=snp).
SNP microarray is a powerful genome research technique designed for the identification of SNP and dose change within the whole genome [29-31]. This method has been widely used to investigate SNP copy number change and $\mathrm{LOH}$ in cancer genome in a variety of medical and biological subjects [32-42]. However, there has been no report describing the use of SNP microarray to assess genomewide SNP copy number change and LOH in SS in the literature (http:// www.ncbi.nlm.nih.gov/sites/entrez).

To address this issue we initially performed SNP microarray on DNA samples isolated from biopsies of skin lesions and peripheral blood mononuclear cells (PBMCs) of patients with SS by using Affymetrix GeneChip Mapping 10K Xba assay. Then we assessed gene-specific SNP copy number changes in same DNA samples with ABI TaqMan SNP genotyping assays to compare and verify the findings from Affymetrix 10K SNP microarray analysis. Finally, we conducted a literature review on LOH findings of patients with SS. Our findings are presented here in this paper. 


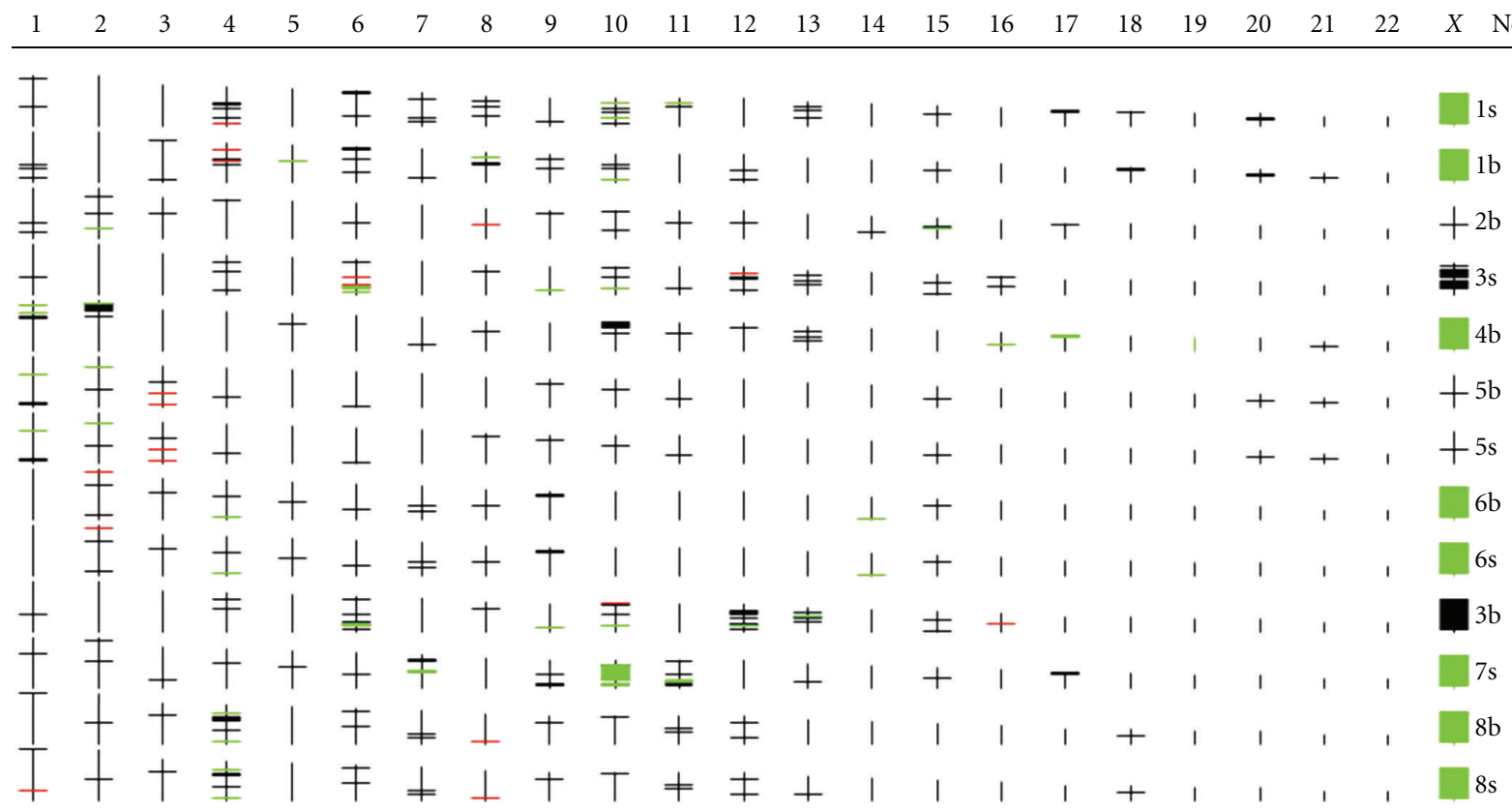

FIGURE 1: Illustration of a diagram of genomewide SNP homozygosity mapping in 8 SS cases (No. 1-8) detected with Affymetrix GeneChip Human Mapping 10K Array (http://www.affymetrix.com/products/arrays/specific/10k.affx) and analysed by using GOLF software (https://bioinformatics.cancerresearchuk.org/cazier01). Here each red-coloured line represents copy number gain of individual SNP, greencoloured line and block stand for SNP copy number loss, black-coloured line and block denote balanced/neutral SNP copy number or uniparental disomy. Similar SNP homozygosity profile is present in paired DNA samples from the biopsied skin lesion (S) and peripheral blood (B) isolated from individual patient with SS on the right end of the diagram. Frequent SNP homozygous changes ( $>3$ ) are seen on almost all autosomes consistent with SNP copy number alterations shown in Figure 2. The remarkable changes on X chromosome were used as the internal quality control for the 10K SNP array experiment as green represents X chromosome copy number loss or monosomy indicating male sex, and black signifies balanced or disomy X chromosome denoting female.

\section{Materials and Methods}

2.1. Sample Selection and DNA Preparation. Eleven patients with Sézary syndrome were selected for this study according to the World Health Organization and the European Organization for Research and Treatment of Cancer diagnosis criteria for CTCL [2]. Genomewide SNP analysis was performed on 8 of these SS cases using Affymetrix SNP microarray. Five of these 8 SS cases plus additional 3 cases were further assessed with SNP quantitative realtime PCR in this study. Briefly, a total of 16 DNA samples (13 samples for SNP microarray and 3 additional samples for SNP qPCR), which were taken prior to treatment, were extracted from both PBMCs and biopsied skin lesions from these SS cases (Figures 1 and 2). This was conducted by using QIAGEN Genomic-tip 100/G kit (QIAGEN Ltd, West Sussex, UK) according to the manufacturer's instruction (http://wwwl.qiagen.com/). DNA concentrations and purity were determined with the NanoDrop ND-1000 spectrophotometer (NanoDrop, Rockland, Del, USA). Local ethical approval for the sampling procedures was obtained previously [9-11, 18] and the use of the stored DNA samples for this study was approved by the Research Ethical Committee at Barts and Royal London School of Medicine and Dentistry, Queen Mary University of London.

2.2. Single Nucleotide Polymorphism Microarray Assay. Affymetrix SNP microarray analysis of 13 DNA samples in- cluding 5 paired PBMCs and skin biopsies from 8 SS patients (Figure 1) was conducted according to the standard GeneChip Mapping $10 \mathrm{~K}$ (V2.0) Xba Assay protocol (Affymetrix Inc., Santa Clara, Calif, USA). Briefly, $350 \mathrm{ng}$ of DNA was digested with XbaI and ligation to the XbaI adaptor prior to PCR amplification (35 cycles) using AmpliTaq Gold with Buffer II (Applied Biosystems, Foster City, Calif, USA). Hybridised arrays were processed with an Affymetrix Fluidics Station 450 and fluorescence signals were detected using the Affymetrix GeneChip Scanner 3000. Signal intensity data was assessed with the GeneChip DNA analysis software (http://www.affymetrix.com/products/arrays/specific/ 10k.affx) based on a model algorithm to generate SNP calls [43] and subsequent bioinformative analysis was carried out using an in-house software called GOLF (http://www.bioinformatics.cancerresearchuk.org/cazier01) developed by Professor Young [44] and a publicly accessible software named IdeogramBrowser Software (http://www.informatik .uni-ulm.de/ni/staff/HKestler/ideo/doc.html).

2.3. SNP Quantitative Real-Time PCR Assay. To verify the results of Affymetrix SNP microarray analysis of SS cases in this study, SNP qPCR assay was performed to test 10 DNA samples from $8 \mathrm{SS}$ patients including 7 samples from $5 \mathrm{SS}$ cases used in above SNP microarray and 3 samples from additional 3 SS cases (Figure 3 ). This experiment was carried out by means of an ABI Prism 7900 sequence detection 

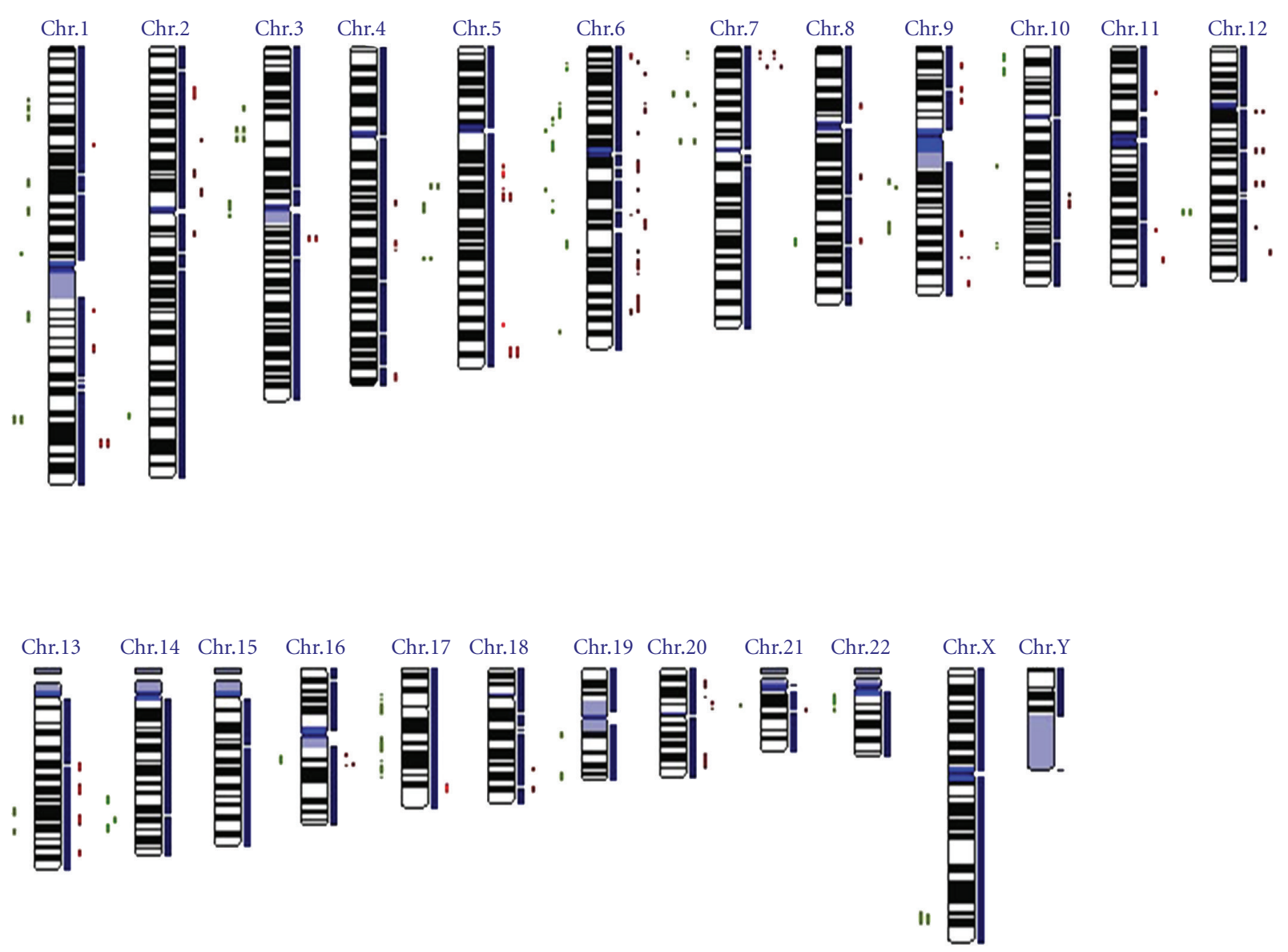

FIGURE 2: Illustration of an ideogram of genomewide SNP copy number changes in 8 SS cases identified by using Affymetrix GeneChip Human Mapping 10K Array as above and analysed with the IdeogramBrowser Software (http://www.informatik.uniulm.de/ni/staff/HKestler/ideo/doc.html). Here each red-coloured dot represents copy number loss of individual SNP and green-coloured dot stands for SNP copy number gain. Frequent SNP copy number changes at chromosomes 1, 2p, 3, 4q, 5q, 6, 7p, 8, 9, 10, 11, 12q, 13, 14, $16 \mathrm{q}, 17$, and 20 are clearly visible.

\begin{tabular}{|c|c|c|c|c|c|c|c|c|c|c|c|c|c|}
\hline Gene & SNP & TaqMan SNP genotyping assay ID & Location & SSla & SS1b & SS3 & SS5a & SS5b & SS6 & SS8 & SS9 & SS10 & SS11 \\
\hline RAB1A & rs10519011 & C_30505234_20 & $2 \mathrm{p} 14$ & & & & & & & & & & \\
\hline STAT4 & rs13001658 & C_26419547_10 & $2 q 32.2 q 32.3$ & & & & & & & & & & \\
\hline VEGFC & $\underline{\mathrm{rs} 1485765}$ & C_8850347_20 & $4 \mathrm{q} 34.1 \mathrm{q} 34.3$ & & & & & & & & & & \\
\hline FAT & rs1280100 & C_11250338_10 & $4 q 35$ & & & & & & & & & & \\
\hline TWIST1 & $\underline{\mathrm{rs} 2106892}$ & C_26517452_10 & $7 \mathrm{p} 21.2$ & & & & & & & & & & \\
\hline BNIP3L & rs1042992 & C_ 8796859_20 & $8 \mathrm{p} 21$ & & & & & & & & & & \\
\hline NFIB & rs2078463 & C_16110577_10 & $9 \mathrm{p} 24.1$ & & & & & & & & & & \\
\hline AKR1C3 & rs7068685 & C_11654325_20 & 10 p15p14 & & & & & & & & & & \\
\hline TAGLN & $\underline{\text { rs2269397 }}$ & C_26872972 10 & $11 \mathrm{q} 23.2$ & & & & & & & & & & \\
\hline NFIB & rs2382446 & C_27086526_10 & chr12 & & & & & & & & & & \\
\hline TRIM16 & rs9909923 & C_30222562_10 & $17 \mathrm{p} 11.2$ & & & & & & & & & & \\
\hline PLS3 & rs5987755 & C_30587612_20 & $\mathrm{Xq} 23$ & & & & & & & & & & \\
\hline
\end{tabular}

FIGURE 3: A summary of SNP copy number changes of 12 genes in 10 SS samples by using qPCR with ABI TaqMan SNP genotyping assay to verify the results of Affymetrix 10K SNP microarray analysis of SS in this study. Here red-coloured rectangular bar denotes SNP copy number loss against internal controls of B2M and GAPDH, green-coloured bar stands for SNP copy number gain, yellow-coloured bar represents balanced/neutral or normal SNP copy number, and gray-coloured bar indicates noninformative. Frequent SNP copy number losses of VEGFC, FAT, NFIB, and TRIM16 are clearly visible. 
system using the TaqMan PCR Master Mix with TaqMan SNP genotyping assays (http://www3.appliedbiosystems.com/applicationstechnolo-gies/real-timepcr/index.htm). These assays amplify 12 genes within the chromosomal regions showing frequent SNP copy number changes identified in this study (Figure 2). Additional 2 SNP genotyping assays amplifying beta-2-microglobulin (B2M, rs935885, C. 12080829_10) and glyceraldehyde-3-phosphate dehydrogenase (GAPDH, rs3741918, C_27510362_10) were used as the internal quality controls. $\mathrm{qPCR}$ reactions contained $900 \mathrm{nmol}$ primers, $200 \mathrm{nmol}$ probes, $400 \mathrm{mM}$ each dATP, dCTP and dGTP, $800 \mathrm{mM}$ dUTP, 1 U Amplitaq Gold DNA polymerase, $0.2 \mathrm{U}$ AmpErase uracil N-glycosylase (UNG), and 13 TaqMan buffer in a total volume of $25 \mu \mathrm{L}$ in 96-well microtiter plate (Applied Biosystems). After a decontamination step at $50^{\circ} \mathrm{C}$, a two-step protocol was followed for 50 cycles: $95^{\circ} \mathrm{C}$ for $15 \mathrm{~s}$ and $61^{\circ} \mathrm{C}$ for $1 \mathrm{~min}$. SNP qPCR data analysis was conducted as previously described [45] with ABI SNPbrowser Software (http://marketing.appliedbiosystems.com/mk/get/snpb_landing).

2.4. SNP Loss of Heterozygosity Expression Profiling. We have previously put forward a concept of functional copy number changes in cancer cells [46]. To further test our hypothesis in this study, we assume a SNP LOH gene cluster in SS is bioinformatically significant or functional if it is capable of separating all SS cases from normal control (NC) samples. This test was carried out through a data mining experiment by using a bioinformative method developed by us [46]. In this experiment, the effect of SNP LOH detected in this study on gene expression profiling in SS cases conducted in previous studies $[23,24,47]$ was tested as before [46]. The procedures were briefly described as follows. We initially created gene lists from 9 chromosomal regions showing frequent $\mathrm{LOH}$ ( $>3$ per region) at SNP level seen in SS (Table 1) by using IdeogramBrowser Software and UCSC Human Gene Sorter (http://www.genome.ucsc.edu/). Then we imported these 9 gene-lists into GeneSpring software version 7 (http://www.sigenetics.com/), which contained a genome/raw data of gene expression profile from 6 SS patients who were treated with photopheresis therapy and 2 healthy individuals generated by using Affymetrix GeneChip U133A (http://www.affymetrix.com/products/arrays/specific/hgu133av2.affx). Of 6 SS cases analysed with Affymetrix gene expression microarray the 3 cases were also tested by above Affymetrix SNP microarray. Finally, we analysed the selected 9 gene lists by using the clustering tool of GeneSpring to generate gene tree and condition tree, a supervised clustering, which enables direct visualisation of sample congregation and separation [46].

2.5. Comparison with Published Data on LOH at Microsatellite Loci in SS. The genomic region where SNPs span on Affymetrix $10 \mathrm{~K}$ GeneChip used in this study is equivalent to that covered by 400 microsatellite (MS) loci (http://www.affymetrix.com/products/arrays/specific/10k.affx). There have been several publications describing $\mathrm{LOH}$ at MS loci on limited chromosomes in CTCL including SS $[9,15-19,48]$.
TABLE 1: A summary of gene expression profile of $\mathrm{LOH}$ gene clusters.

\begin{tabular}{lcc}
\hline $\begin{array}{l}\text { Chromosomal regions } \\
\text { with LOH detected in } \\
\text { this study }\end{array}$ & $\begin{array}{c}\text { Number of genes } \\
\text { 1p36p33 }\end{array}$ & $\begin{array}{c}\text { Separation of SS } \\
\text { from NC* }\end{array}$ \\
$2 \mathrm{q} 21 \mathrm{q} 24$ & 80 & $\mathrm{~N}$ \\
$8 \mathrm{q} 22 \mathrm{q} 24$ & 15 & $\mathrm{~N}$ \\
$9 \mathrm{q} 31 \mathrm{q} 34$ & 40 & $\mathrm{~N}$ \\
$10 \mathrm{p} 11 \mathrm{q} 26$ & 111 & $\mathrm{P}$ \\
$11 \mathrm{q} 21 \mathrm{q} 25$ & 205 & $\mathrm{P}$ \\
$13 \mathrm{q} 11 \mathrm{q} 12$ & 15 & $\mathrm{~N}$ \\
$16 \mathrm{q} 21 \mathrm{q} 23$ & 74 & $\mathrm{P}$ \\
$17 \mathrm{p} 13 \mathrm{q} 11$ & 198 & $\mathrm{~N}$ \\
\hline
\end{tabular}

${ }^{*} \mathrm{~N}$ : no separation between SS and NC, P: presence of separation between SS and NC.

To compare previous findings with this study, we reanalysed previous published data on MS LOH at chromosomes 1 and 10q through fine mapping of each MS locus, which was linked to individual gene and SNP by using NCBI ENTREZ GENE and ENTREZ SNP database (http://www .ncbi.nlm.nih.gov/).

\section{Results}

3.1. SNP Microarray. In this study, paired DNA samples from PBMCs and skin lesions from 5 of 8 SS cases were analysed with Affymetrix $10 \mathrm{~K}$ SNP microarray, which showed similar SNP homozygous changes between the paired samples indicating they are coming from the same individual. There was a difference in SNP fingerprint among 8 different SS cases signifying the absence of sample contamination. As Figure 1 shows, frequent homozygous changes ( $>3$ per chromosome) including gain, loss, and uniparental disomy (UPD) were seen to distribute throughout almost an entire genome except of chromosomes 14, 19 and 22.

As Figure 2 shows there were frequent SNP copy number changes ( $>3$ per chromosome) at chromosomes $1,2 \mathrm{p}, 3,4 \mathrm{q}$, $5 q, 6,7 p, 8,9,10,11,12 q, 13,14,16 q, 17$, and 20 , which are not only consistent with above homozygous changes but also in line with previous CGH findings in SS [10].

In this study, a weak and/or smear band of TCR gene was detected in skin DNA samples, while a strong monoclonal TCR gene band was seen in PBMC DNA samples (data not shown), suggesting that only a few tumour cells were present in skin samples and sample contamination was negligible. Overall, a frequent $\mathrm{LOH}$ was noted in 5 paired SS cases at 9 chromosomal regions including 1p36p33, 2q21q24, 8q22q24, 9q31q34, 10p11q26, 11q21q25, 13q11q12, 16q21q23, and 17p13q11 (Table 1), which are to some extent similar to previous reports on $\mathrm{LOH}$ at certain chromosome regions $[9,15-19]$.

3.2. SNP qPCR Assay. To further confirm SNP microarray findings, SNP qPCR was utilised to test DNA samples from 5 of 8 SS cases (case number 1, 3, 5, 6 and 8) analysed with 
Affymetrix 10K SNP microarray using ABI TaqMan SNP genotyping assay (63\%) and 3 additional cases. As Figure 3 shows, frequent SNP copy number loss ( $>2$ cases) at the FAT gene (rs1280100) at 4q35 was observed in 6 of 8 SS cases (number 1, 3, 6, 8, 9, and 10) (75\%), followed by VEGFC (rs1485765) at 4q34.1q34.3 (cases 3, 6, 8, and 9) (50\%), NFIB (rs2382446) at chromosome 12 (cases 5, 6 and 8) (38\%), and TRIM16 (rs9909923) at 17p11.2 (cases 3, 6, and 8$)(38 \%)$. While frequent SNP copy number gain $(>2$ cases) was also noted at the AKR1C3 gene (rs7068685, 50\%), VEGFC (rs1485765, 38\%), and TAGLN (rs2269397, 38\%).

SNP copy number changes were most frequent present in SS case 3, which showed losses of genes of RAB1A (rs10519011, 2p14), VEGFC, FAT, AKR1C3, TRIM16, and PLS3 (rs5987755, Xq23) as well as gains of genes of TAGLN (rs2269397, 11q23.2) and NFIB. This was followed by case 5, which had gains of RAB1A, STAT4 (rs13001658, 2q32.2q32.3), VEGFC, TWIST1 (rs2106892, 7p21.2), TAGLN, and PLS3, and loss of NFIB. Case 6 revealed losses of VEGFC, FAT, NFIB and TRIM16, and gain of AKR1C3; case 8 demonstrated losses of VEGFC, FAT, AKR1C3, NFIB, and TRIM16 (Figure 3). Overall these SNP copy number changes, detected by using qPCR with ABI TaqMan SNP genotyping assay, were consistent with those identified by using Affymetrix 10K SNP microarray as shown in Figure 2.

\subsection{SNP LOH Expression Profiling. The impact of SNP LOH} gene cluster on gene expression pattern was further tested in this study. As shown in Figure 4, the clusters of 2 NCs appeared at the right end of the heatmap and the clusters of 6 SS cases were present in the middle and at the left end of the heatmap. This clearly showed that two groups were separated and different. Over the 9 SNP LOH gene lists analysed in this study, 3 (33\%) showed gene expression patterns of the separation of 6 SS cases from 2 NCs (Table 1). This included SNP LOH gene clusters at 9q31q34 (40 genes), 10p11q26 (111 genes), and 13q11q12 (15 genes) (Figure 4). Each individual gene in these 3 gene clusters is listed in Table 2. However, the remaining 6 SNP LOH gene lists revealed a mixed gene expression pattern without the separation of SS from NCs (Table 1).

3.4. Refining Previous SS LOH Data and Comparing with This Study. Previous studies have shown $\mathrm{LOH}$ on several chromosomes including chromosomes 1 and $10 \mathrm{q}[9,15-$ $19,48]$. The $10 \mathrm{~K}$ SNP microarray gene chip used in this study is equivalent to the genetic distance covered by $400 \mathrm{MS}$. This allows us to compare SNP LOH identified in this study with MS LOH described in those previous studies. Frequent LOH at MS loci D1S247 (rs11372930) at 1p36 and D10S562 (rs4128597) at 10q25.3 (Figure 5) reported in previous studies $[9,18,19]$ were seen in this study.

\section{Discussion}

This integrated genomic study has for the first time revealed genomewide SNP copy number change and $\mathrm{LOH}$ as well as SNP LOH gene expression profiling in SS cases. Although the number of SS cases tested in this study was small, the patterns of SNP copy number change and LOH identified in SS cases are generally in line with previous metaphase/array-CGH [6-14] and MS LOH studies [9, 15, 17-19, 48], suggesting the high efficiency and reliability of the methods used. In addition some novel findings emerged. This includes the presence of SNP copy number loss at the FAT gene (4q35) in most SS cases and the separation of all SS cases from NC samples by SNP LOH gene clusters at chromosome regions of 9q31q34, 10p11q26, and 13q11q12. Although all of these results will need to be validated in larger cohorts of samples from SS patients in the future, they do provide some intriguing information for our current understanding of the molecular pathogenesis of this type of lymphoma and suggest the possibility of presence of functional SNP LOH in SS tumour cells at least from the point of view of bioinformatics.

Sézary syndrome is a rare form of CTCL with an aggressive clinical course and it also likely represents the leukaemic phase of mycosis fungoides $[1,2]$. Like any other advanced stage of malignancies, SS accumulates a variety of genetic and epigenetic events including alterations of tumour suppressor genes, oncogenes, and some key house-keeping genes [18, 27, $28,49]$. Previous studies on SS have shown complex genetic aberrations affecting almost all chromosomes with copy number losses being the dominant abnormalities, which mainly involve chromosomes $1 \mathrm{p}, 6 \mathrm{q}, 9,10,13 \mathrm{q}$, and $17 \mathrm{p}$ [6-14] and the presence of LOH at MS loci on chromosomes $1 p, 9 p, 10 q$, and $17 p$ in tumour cells $[9,15-19,48]$. In addition, downregulation of several genes including MXI1 (10q24q25) and upregulation of genes such as TWIST1 (7p21.2) and PLS3 (Xq23) have also been described in this malignancy [20-26]. Similar results were obtained in this study, which showed SNP copy number change on chromosomes 1, 2p, 3, 4q, 5q, 6, 7p, 8, 9, 10, 11, 12q, 13, 14, 16q, 17, and 20 , and $\mathrm{LOH}$ at $1 \mathrm{p}, 2 \mathrm{q}, 8 \mathrm{q}, 9 \mathrm{q}, 10,11 \mathrm{q}, 13 \mathrm{q}, 16 \mathrm{q}$, and 17 as well as SNP copy number gains of TWIST1 and PLS3 in 2 SS cases, further indicating the high efficiency and reliability of the integrated genomic experiments conducted in this study.

Although there are different definitions for loss of heterozygosity in literature, $\mathrm{LOH}$ is generally defined as a locus or loci at which a deletion or other process has converted the locus from heterozygosity to homozygosity or hemizygosity. In terms of cancer, LOH signifies that in tumour cells carrying a mutated allele of a tumour suppressor gene, the gene becomes fully inactivated when the cell loses a large part of the chromosome carrying the wild-type allele (http://www.ncbi.nlm.nih.gov/cancerchromosomes). $\mathrm{LOH}$ is traditionally used as a molecular tool to identify a tumoursuppressor gene but it also represents one of the most common molecular features of cancer cells [47, 50-52]. Previous studies have shown LOH at MS loci on chromosomes $1 \mathrm{p}$, $9 \mathrm{p}, 10 \mathrm{q}, 12 \mathrm{q}, 13 \mathrm{q}, 17 \mathrm{p}$, and 19 in CTCL including SS [9, 15$19,48]$. This was supported by previous conventional cytogenetics and metaphase and array-based CGH studies, which revealed DNA copy number losses at these chromosomal regions $[6-14,48]$. In this study $\mathrm{LOH}$ at SNP level on 9 chromosomal regions $(1 \mathrm{p}, 2 \mathrm{q}, 8 \mathrm{q}, 9 \mathrm{q}, 10,11 \mathrm{q}, 13 \mathrm{q}, 16 \mathrm{q}$, and 17) 


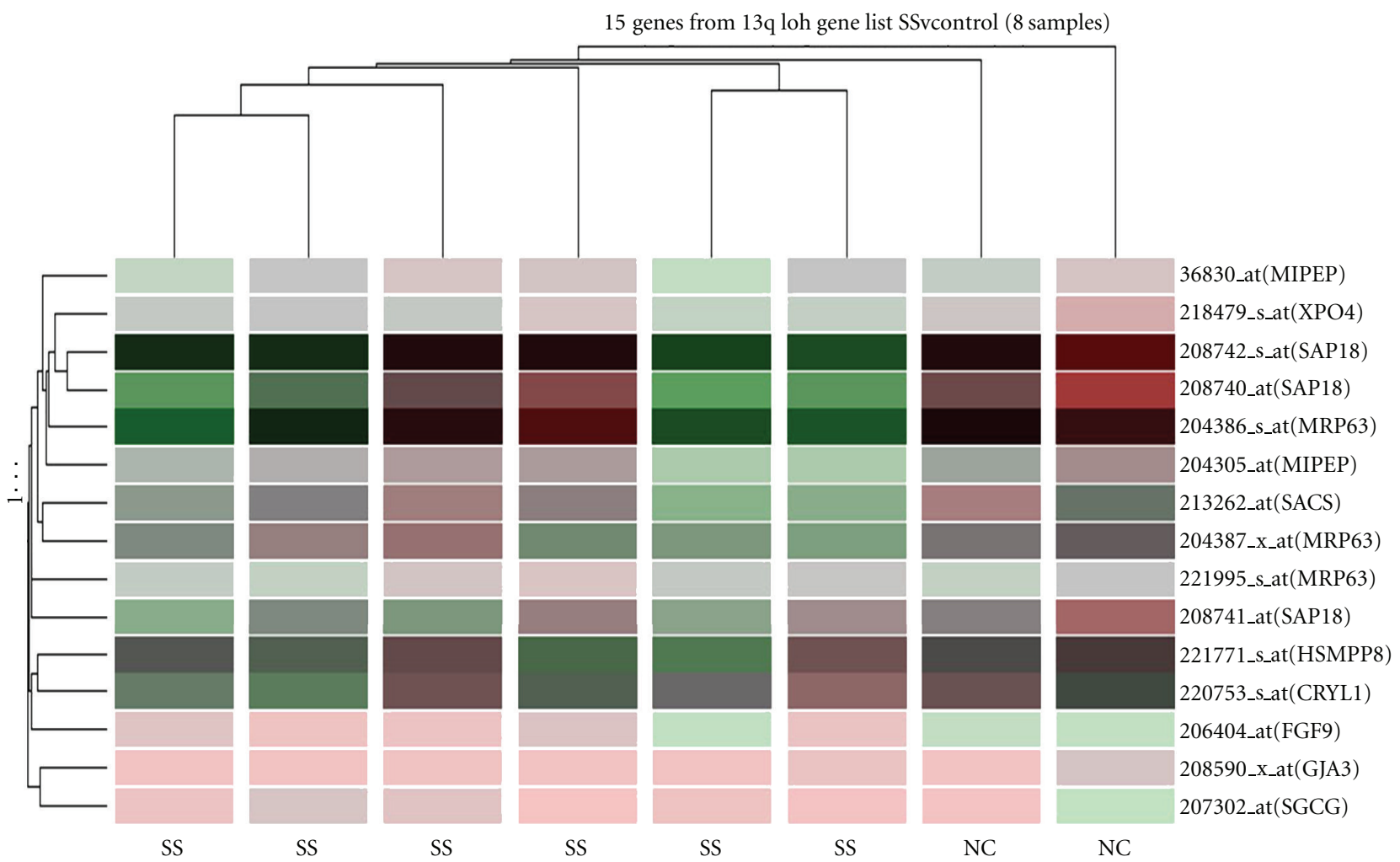

FIGURE 4: Illustration of a heatmap of gene expression profile of SNP LOH at 13q11q12 gene cluster (15 genes). Here each column represents one test sample and each coloured rectangular bar signifies each individual gene. The colouration of each bar indicates the expression level of individual gene, which has been reported previously $[23,24,47]$ and is not the focus of this study. The separation of 6 Sézary syndrome cases (SS, left and middle) from 2 normal controls (NC, right) is clearly visible and two test groups are different.

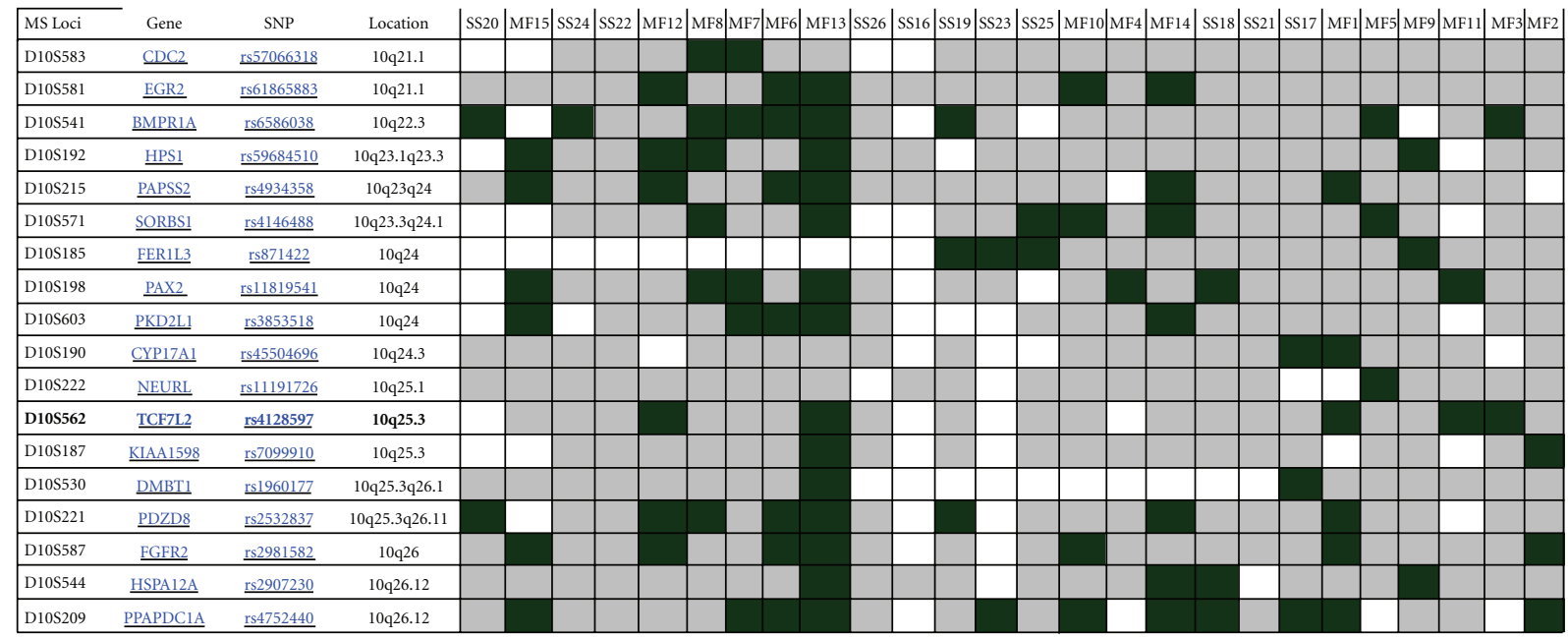

FIGURE 5: A summary of reanalysis of previously published LOH at 18 microsatellite loci on 10q21q26 in SS and MF [19] with this study, in which each microsatellite locus is finely mapped and linked to individual gene and SNP via NCBI ENTREZ GENE and ENTREZ SNP database (http://www.ncbi.nlm.nih.gov/). Here black bar represents LOH, gray bar stands for noninformative, and white bar indicates microsatellite marker that is not available. One SNP within microsatellite locus D10S562 (bold) is also present in the SNP LOH cluster at $10 \mathrm{p} 11 \mathrm{q} 26$ in this study (Table 1). 
TABLE 2: A detailed gene list of the $3 \mathrm{LOH}$ gene clusters separating SS from NC

\begin{tabular}{|c|c|c|c|}
\hline LOH gene clusters & Gene name & Common & Description \\
\hline \multirow[t]{40}{*}{$9 q 31 q 34$} & 221294_at & GPR21 & G-protein-coupled receptor 21 \\
\hline & 221085_at & TNFSF15 & Tumor necrosis factor (ligand) superfamily, member 15 \\
\hline & 220935_s_at & CDK5RAP2 & CDK5 regulatory subunit associated protein 2 \\
\hline & 220300_at & RGS3 & Regulator of G-protein signalling 3 \\
\hline & 220202_s_at & MNAB & Membrane-associated nucleic acid binding protein \\
\hline & 220201_at & MNAB & Membrane-associated nucleic acid binding protein \\
\hline & 219884_at & LHX6 & LIM homeobox protein 6 \\
\hline & 218941_at & FBXW2 & F-box and WD-40 domain protein 2 \\
\hline & 218489_s_at & ALAD & Aminolevulinate, delta-, dehydratase \\
\hline & 218487_at & ALAD & Aminolevulinate, delta-, dehydratase \\
\hline & 218160_at & NDUFA8 & NADH dehydrogenase (ubiquinone) 1 alpha subcomplex, $8,19 \mathrm{kDa}$ \\
\hline & 215813_s_at & PTGS1 & $\begin{array}{l}\text { Prostaglandin-endoperoxide synthase } 1 \text { (prostaglandin } \mathrm{G} / \mathrm{H} \text { synthase and } \\
\text { cyclooxygenase) }\end{array}$ \\
\hline & 214465_at & ORM2 & Orosomucoid 2 \\
\hline & 214425_at & AMBP & Alpha-1-microglobulin/bikunin precursor \\
\hline & 214040_s_at & GSN & Gelsolin (amyloidosis, Finnish type) \\
\hline & 211503_s_at & RAB14 & RAB14, member RAS oncogene family \\
\hline & 210825_s_at & STOM & Stomatin \\
\hline & 210824_at & STOM & Stomatin \\
\hline & 209162_s_at & PRPF4 & PRP4 pre-mRNA processing factor 4 homolog (yeast) \\
\hline & 209161_at & PRPF4 & PRP4 pre-mRNA processing factor 4 homolog (yeast) \\
\hline & 208828_at & POLE3 & Polymerase (DNA directed), epsilon 3 (p17 subunit) \\
\hline & 208737_at & ATP6V1G1 & ATPase, $\mathrm{H}+$ transporting, lysosomal $13 \mathrm{kDa}, \mathrm{V} 1$ subunit $\mathrm{G}$ isoform 1 \\
\hline & 205599_at & TRAF1 & TNF receptor-associated factor 1 \\
\hline & 205500_at & C5 & Complement component 5 \\
\hline & 205477_s_at & AMBP & Alpha-1-microglobulin/bikunin precursor \\
\hline & 205128_x_at & PTGS1 & $\begin{array}{l}\text { Prostaglandin-endoperoxide synthase } 1 \text { (prostaglandin G/H synthase and } \\
\text { cyclooxygenase) }\end{array}$ \\
\hline & 205127_at & PTGS1 & $\begin{array}{l}\text { Prostaglandin-endoperoxide synthase } 1 \text { (prostaglandin G/H synthase and } \\
\text { cyclooxygenase) }\end{array}$ \\
\hline & 205041_s_at & ORM1 & Orosomucoid 1 \\
\hline & 205040_at & ORM1 & Orosomucoid 1 \\
\hline & 204449_at & PDCL & Phosducin-like \\
\hline & 204448_s_at & PDCL & Phosducin-like \\
\hline & 203971_at & SLC31A1 & Solute carrier family 31 (copper transporters), member 1 \\
\hline & 203823_at & RGS3 & Regulator of G-protein signalling 3 \\
\hline & 203447_at & PSMD5 & Proteasome (prosome, macropain) 26S subunit, non-ATPase, 5 \\
\hline & 201062_at & STOM & Stomatin \\
\hline & 201061_s_at & STOM & Stomatin \\
\hline & 201060_x_at & STOM & Stomatin \\
\hline & 200928_s_at & RAB14 & RAB14, member RAS oncogene family \\
\hline & 200927_s_at & RAB14 & RAB14, member RAS oncogene family \\
\hline & 200696_s_at & GSN & Gelsolin (amyloidosis, Finnish type) \\
\hline \multirow[t]{7}{*}{$10 \mathrm{p} 11.21 \mathrm{q} 26.3$} & 32094_at & CHST3 & Carbohydrate (chondroitin 6) sulfotransferase 3 \\
\hline & 222072_at & ADD3 & Homo sapiens clone DT1P1A11 mRNA, CAG repeat region \\
\hline & 221136_at & GDF2 & Growth differentiation factor 2 \\
\hline & 219963_at & DUSP13 & Dual specificity phosphatase 13 \\
\hline & 219957_at & RUFY2 & RUN and FYVE domain containing 2 \\
\hline & 219543_at & MAWBP & MAWD binding protein \\
\hline & 219509_at & MYOZ1 & Myozenin 1 \\
\hline
\end{tabular}


Table 2: Continued.

\begin{tabular}{|c|c|c|c|}
\hline LOH gene clusters & Gene name & Common & Description \\
\hline & 218878_s_at & SIRT1 & $\begin{array}{l}\text { Sirtuin (silent mating type information regulation } 2 \text { homolog) } 1 \text { ( } S \text {. } \\
\text { cerevisiae) }\end{array}$ \\
\hline & 218871_x_at & GALNACT-2 & Chondroitin sulfate GalNAcT-2 \\
\hline & 218445_at & H2AFY2 & H2A histone family, member Y2 \\
\hline & 218249_at & ZDHHC6 & Zinc finger, DHHC domain containing 6 \\
\hline & 218046_s_at & MRPS16 & Mitochondrial ribosomal protein S16 \\
\hline & 218006_s_at & ZNF22 & Zinc finger protein 22 (KOX 15) \\
\hline & 218005_at & ZNF22 & Zinc finger protein 22 (KOX 15) \\
\hline & 216903_s_at & CBARA1 & Calcium binding atopy-related autoantigen 1 \\
\hline & 216345_at & KIAA0913 & KIAA0913 protein \\
\hline & 216037_x_at & TCF7L2 & Transcription factor 7-like 2 (T-cell specific, HMG-box) \\
\hline & 216035_x_at & TCF7L2 & Transcription factor 7-like 2 (T-cell specific, HMG-box) \\
\hline & 214878_at & ZNF37A & Zinc finger protein $37 \mathrm{a}(\mathrm{KOX} 21)$ \\
\hline & 214617_at & PRF1 & Perforin 1 (pore forming protein) \\
\hline & 214508_x_at & CREM & cAMP responsive element modulator \\
\hline & 214366_s_at & ALOX5 & Arachidonate 5-lipoxygenase \\
\hline & 214348_at & TACR2 & Tachykinin receptor 2 \\
\hline & 214338_at & DNAJB12 & DnaJ (Hsp40) homolog, subfamily B, member 12 \\
\hline & 214322_at & CAMK2G & Calcium/calmodulin-dependent protein kinase (CaM kinase) II gamma \\
\hline & 214136_at & NUDT13 & Nudix (nucleoside diphosphate linked moiety X)-type motif 13 \\
\hline & 213952_s_at & ALOX 5 & Arachidonate 5-lipoxygenase \\
\hline & 213647_at & DNA2L & DNA2 DNA replication helicase 2-like (yeast) \\
\hline & 212894_at & SUPV3L1 & Suppressor of var1, 3-like 1 (S. cerevisiae) \\
\hline & 212762_s_at & TCF7L2 & Transcription factor 7-like 2 (T-cell specific, HMG-box) \\
\hline & 212761_at & TCF7L2 & Transcription factor 7-like 2 (T-cell specific, HMG-box) \\
\hline & 212759_s_at & TCF7L2 & Transcription factor 7-like 2 (T-cell specific, HMG-box) \\
\hline & 212757_s_at & CAMK2G & Calcium/calmodulin-dependent protein kinase (CaM kinase) II gamma \\
\hline & 212669_at & CAMK2G & Calcium/calmodulin-dependent protein kinase (CaM kinase) II gamma \\
\hline & 212594_at & PDCD4 & Programmed cell death 4 (neoplastic transformation inhibitor) \\
\hline & 212593_s_at & PDCD4 & Programmed cell death 4 (neoplastic transformation inhibitor) \\
\hline & 212359_s_at & KIAA0913 & KIAA0913 protein \\
\hline & 212322_at & SGPL1 & Sphingosine-1-phosphate lyase 1 \\
\hline & 212321_at & SGPL1 & Sphingosine-1-phosphate lyase 1 \\
\hline & 211809_x_at & COL13A1 & Collagen, type XIII, alpha 1 \\
\hline & 211668_s_at & PLAU & plasminogen activator, urokinase \\
\hline & 211343_s_at & COL13A1 & Collagen, type XIII, alpha 1 \\
\hline & 210956_at & PPYR1 & Pancreatic polypeptide receptor 1 \\
\hline & 210671_x_at & MAPK8 & Mitogen-activated protein kinase 8 \\
\hline & 210588_x_at & HNRPH3 & Heterogeneous nuclear ribonucleoprotein $\mathrm{H} 3$ (2H9) \\
\hline & 210477_x_at & MAPK8 & Mitogen-activated protein kinase 8 \\
\hline & 210318_at & RBP3 & Retinol binding protein 3 , interstitial \\
\hline & 210171_s_at & CREM & cAMP responsive element modulator \\
\hline & 210110_x_at & HNRPH3 & Heterogeneous nuclear ribonucleoprotein H3 (2H9) \\
\hline & 209910_at & SLC25A16 & $\begin{array}{l}\text { Solute carrier family } 25 \text { (mitochondrial carrier; Graves disease } \\
\text { autoantigen), member } 16\end{array}$ \\
\hline & 209869_at & ADRA2A & Adrenergic, alpha-2A-, receptor \\
\hline & 209860_s_at & ANXA7 & Annexin A7 \\
\hline & 209834_at & CHST3 & Carbohydrate (chondroitin 6) sulfotransferase 3 \\
\hline & 209817_at & РPР3СB & $\begin{array}{l}\text { Protein phosphatase } 3 \text { (formerly 2B), catalytic subunit, beta isoform } \\
\text { (calcineurin A beta) }\end{array}$ \\
\hline
\end{tabular}


Table 2: Continued.

\begin{tabular}{|c|c|c|c|}
\hline LOH gene clusters & Gene name & Common & Description \\
\hline & 209538_at & ZNF32 & Zinc finger protein $32(\mathrm{KOX} 30)$ \\
\hline & 209457_at & DUSP5 & Dual specificity phosphatase 5 \\
\hline & 209045_at & XPNPEP1 & X-prolyl aminopeptidase (aminopeptidase P) 1, soluble \\
\hline & 208990_s_at & HNRPH3 & Heterogeneous nuclear ribonucleoprotein H3 (2H9) \\
\hline & 208770_s_at & EIF4EBP2 & Eukaryotic translation initiation factor $4 \mathrm{E}$ binding protein 2 \\
\hline & 208769_at & EIF4EBP2 & Eukaryotic translation initiation factor $4 \mathrm{E}$ binding protein 2 \\
\hline & 208535_x_at & COL13A1 & Collagen, type XIII, alpha 1 \\
\hline & 208453_s_at & XPNPEP1 & X-prolyl aminopeptidase (aminopeptidase P) 1, soluble \\
\hline & 208381_s_at & SGPL1 & Sphingosine-1-phosphate lyase 1 \\
\hline & 208252_s_at & CHST3 & Carbohydrate (chondroitin 6) sulfotransferase 3 \\
\hline & 208152_s_at & DDX21 & DEAD/H (Asp-Glu-Ala-Asp/His) box polypeptide 21 \\
\hline & 208095_s_at & CAMK2G & Calcium/calmodulin-dependent protein kinase (CaM kinase) II gamma \\
\hline & 207965_at & NEUROG3 & Neurogenin 3 \\
\hline & 207630_s_at & CREM & cAMP responsive element modulator \\
\hline & 207543_s_at & P4HA1 & $\begin{array}{l}\text { Procollagen-proline, 2-oxoglutarate 4-dioxygenase (proline } \\
\text { 4-hydroxylase), alpha polypeptide I }\end{array}$ \\
\hline & 207347_at & ERCC6 & $\begin{array}{l}\text { Excision repair cross-complementing rodent repair deficiency, } \\
\text { complementation group } 6\end{array}$ \\
\hline & 207127_s_at & HNRPH3 & Heterogeneous nuclear ribonucleoprotein $\mathrm{H} 3$ (2H9) \\
\hline & 206747_at & KIAA0514 & KIAA0514 gene product \\
\hline & 206261_at & ZNF239 & Zinc finger protein 239 \\
\hline & 206159_at & GDF10 & Growth differentiation factor 10 \\
\hline & 206010_at & HABP2 & Hyaluronan binding protein 2 \\
\hline & 205882_x_at & ADD3 & Adducin 3 (gamma) \\
\hline & 205879_x_at & RET & $\begin{array}{l}\text { Ret proto-oncogene (multiple endocrine neoplasia and medullary thyroid } \\
\text { carcinoma 1, Hirschsprung disease) }\end{array}$ \\
\hline & 205479_s_at & PLAU & Plasminogen activator, urokinase \\
\hline & 204446_s_at & ALOX5 & Arachidonate 5-lipoxygenase \\
\hline & 204445_s_at & ALOX5 & Arachidonate 5-lipoxygenase \\
\hline & 204120_s_at & $\mathrm{ADK}$ & Adenosine kinase \\
\hline & 204119_s_at & $\mathrm{ADK}$ & Adenosine kinase \\
\hline & 203916_at & NDST2 & $\mathrm{N}$-deacetylase/N-sulfotransferase (heparan glucosaminyl) 2 \\
\hline & 203666_at & CXCL12 & Chemokine (C-X-C motif) ligand 12 (stromal cell-derived factor 1$)$ \\
\hline & 203187_at & DOCK1 & Dedicator of cyto-kinesis 1 \\
\hline & 203079_s_at & CUL2 & Cullin 2 \\
\hline & 203078_at & CUL2 & Cullin 2 \\
\hline & 203074_at & ANXA8 & Annexin A8 \\
\hline & 202867_s_at & DNAJB12 & DnaJ (Hsp40) homolog, subfamily B, member 12 \\
\hline & 202866_at & DNAJB12 & DnaJ (Hsp40) homolog, subfamily B, member 12 \\
\hline & 202865_at & DNAJB12 & DnaJ (Hsp40) homolog, subfamily B, member 12 \\
\hline & 202777_at & SHOC2 & soc-2 suppressor of clear homolog (C. elegans) \\
\hline & 202731_at & PDCD4 & Programmed cell death 4 (neoplastic transformation inhibitor) \\
\hline & 202730_s_at & PDCD4 & Programmed cell death 4 (neoplastic transformation inhibitor) \\
\hline & 202524_s_at & SPOCK2 & Sparc/osteonectin, cwcv and kazal-like domains proteoglycan (testican) 2 \\
\hline & 202523_s_at & SPOCK2 & Sparc/osteonectin, cwcv and kazal-like domains proteoglycan (testican) 2 \\
\hline & 202432_at & РPР3СB & $\begin{array}{l}\text { Protein phosphatase } 3 \text { (formerly 2B), catalytic subunit, beta isoform } \\
\text { (calcineurin A beta) }\end{array}$ \\
\hline & 202364_at & MXI1 & MAX interacting protein 1 \\
\hline & 202361_at & SEC 24C & SEC24 related gene family, member C (S. cerevisiae) \\
\hline & 201859_at & PRG1 & Proteoglycan 1 , secretory granule \\
\hline
\end{tabular}


Table 2: Continued.

\begin{tabular}{|c|c|c|c|}
\hline \multirow[t]{12}{*}{ LOH gene clusters } & Gene name & Common & Description \\
\hline & 201858_s_at & PRG1 & Proteoglycan 1 , secretory granule \\
\hline & 201753_s_at & ADD3 & Adducin 3 (gamma) \\
\hline & 201752_s_at & ADD3 & Adducin 3 (gamma) \\
\hline & 201376_s_at & HNRPF & Heterogeneous nuclear ribonucleoprotein F \\
\hline & 201366_at & ANXA7 & Annexin A7 \\
\hline & 201034_at & ADD3 & Adducin 3 (gamma) \\
\hline & 200931_s_at & VCL & Vinculin \\
\hline & 200930_s_at & VCL & Vinculin \\
\hline & 200871_s_at & PSAP & $\begin{array}{l}\text { Prosaposin (variant Gaucher disease and variant metachromatic } \\
\text { leukodystrophy) }\end{array}$ \\
\hline & 200866_s_at & PSAP & $\begin{array}{l}\text { Prosaposin (variant Gaucher disease and variant metachromatic } \\
\text { leukodystrophy) }\end{array}$ \\
\hline & 200697_at & HK1 & Hexokinase 1 \\
\hline \multirow[t]{15}{*}{$13 q 11 q 12$} & 36830_at & MIPEP & Mitochondrial intermediate peptidase \\
\hline & 221995_s_at & MRP63 & Mitochondrial ribosomal protein 63 \\
\hline & 221771_s_at & HSMPP8 & M-phase phosphoprotein, mpp8 \\
\hline & 220753_s_at & CRYL1 & Crystallin, lambda 1 \\
\hline & 218479_s_at & XPO4 & Exportin 4 \\
\hline & 213262_at & SACS & Spastic ataxia of Charlevoix-Saguenay (sacsin) \\
\hline & 208742_s_at & SAP18 & $\sin 3$-associated polypeptide, $18 \mathrm{kDa}$ \\
\hline & 208741_at & SAP18 & $\sin 3$-associated polypeptide, $18 \mathrm{kDa}$ \\
\hline & 208740_at & SAP18 & $\sin 3$-associated polypeptide, $18 \mathrm{kDa}$ \\
\hline & 208590_x_at & GJA3 & Gap junction protein, alpha 3, 46 kDa (connexin 46$)$ \\
\hline & 207302_at & SGCG & Sarcoglycan, gamma ( $35 \mathrm{kDa}$ dystrophin-associated glycoprotein) \\
\hline & 206404_at & FGF9 & Fibroblast growth factor 9 (glia-activating factor) \\
\hline & 204387_x_at & MRP63 & Mitochondrial ribosomal protein 63 \\
\hline & 204386_s_at & MRP63 & Mitochondrial ribosomal protein 63 \\
\hline & 204305_at & MIPEP & Mitochondrial intermediate peptidase \\
\hline
\end{tabular}

was identified in SS cases by using Affymetrix $10 \mathrm{~K}$ GeneChip, which covers approximately 400 MS loci. There was an overlap between this and previous studies on $\mathrm{LOH}$ at chromosome 1p (D1S247) and 10q (D10S562). Previous studies also suggested $\mathrm{LOH}$ at $1 \mathrm{p}$ and $10 \mathrm{q}$ associated with late stage CTCL $[15-17,19,48]$. In addition, copy number losses were described in these 9 chromosomal regions by using molecular cytogenetic techniques as discussed above. Furthermore, these findings were subsequently validated by extensive SNP qPCR test in this study. Taking together all of these results suggest that some of these SNP LOH and copy number changes are likely to be associated with the pathogenesis of SS.

The FAT gene, which is expressed at high levels in a number of foetal epithelia, is an ortholog of the Drosophila fat gene. FAT encodes a tumour suppressor essential for controlling cell proliferation during Drosophila development. Its product is a member of the cadherin superfamily, a group of integral membrane proteins characterised by the presence of 34 tandem cadherin-type repeats as well as five epidermal growth factor-like repeats and one laminin A-G domain with possible functions as an adhesion molecule and/or signalling receptor, which are likely to be associated with developmental processes and cell communication (http://www.ncbi.nlm.nih.gov/gene/2195). The FAT gene is located on human chromosome $4 \mathrm{q} 35$. Previous molecular cytogenetic studies have revealed copy number losses at this chromosomal region in a variety of cancers (http://www.progenetix.org/cgi-bin/pgCasesMatrixPlotter.cgi). Furthermore deletion/LOH and absent expression of FAT have also been found in oral cancer [53] and human astrocytic tumours [54]. Intriguingly, in this study SNP copy number loss of FAT was observed in three-quarter of SS cases and reduced gene expression of FAT was also noted in most cutaneous squamous cell carcinoma cases (data not shown) no spare SS RNA samples are available for qPCR testing. These results further indicate the tumour suppressor role of FAT and also suggest that loss of FAT is relevant to SS pathology.

Interindividual copy number variation/polymorphism $(\mathrm{CNV} / \mathrm{P})$ is thought to be the manifestation of a considerable and unanticipated plasticity of the human genome. CNV/P constitutes a major source of interindividual genetic variation that could explain variable penetrance of inherited diseases and variation in the phenotypic expression of aneuploidies and sporadic traits $[55,56]$. There is increasing 
evidence showing de novo $\mathrm{CNV} / \mathrm{P}$ as a major cause of mental retardation and several other complex disorders [38$40,43,57]$. Cytogenetically CNV/P or copy number changes (CNCs) have long been described in cancer cells (http:// www.cgap.nci.nih.gov/Chromosomes/Mitelman, http://www .progenetix.net/). As discussed above SS has been found with frequent CNCs at several chromosomal regions [6-13]. Some of these CNCs may have a net effect on gene expression as previous expression profiling studies on SS have revealed up- and downregulations of several genes, which are mapped within the chromosomal regions harbouring these CNCs [20-26]. From, bioinformatic point of view these CNCs may be functional. Whilst the remaining $\mathrm{CNCs}(\mathrm{CNV} / \mathrm{P})$ may not have any net effect at all and are therefore nonfunctional. To test this hypothesis we developed a simple bioinformatics strategy through the analysis of the expression profiling of CNCs gene clusters commonly presented in SS to see if SS cases can be separated from NCs. We found separated expression patterns in 4 of 17 CNCs gene clusters [46]. In this study, we expanded the scope of our bioinformatics experiment by examining the impact of common SNP LOH gene clusters identified in SS cases with Affymetrix $10 \mathrm{~K} \mathrm{SNP}$ microarray on gene expression patterns in SS cases detected using gene expression microarray with Affymetrix GeneChip U133A and dedicated software. There was a separation of all $6 \mathrm{SS}$ cases from $2 \mathrm{NCs}$ by 3 of 9 SNP LOH gene clusters. This includes 9q31q34, 10p11q26, and 13q11q12, which lie within the chromosomal regions showing frequent LOH and/or DNA copy number loss in SS. In addition, decreased expression of MXI1 in SNP LOH gene cluster at $10 \mathrm{p} 11 \mathrm{q} 26$ has been described in SS previously [22]. All of these findings suggest that the 3 SNP LOH gene clusters may be functional in terms of bioinformatics and relevant to SS pathology. There are also a number of genes in these $3 \mathrm{SNP}$ $\mathrm{LOH}$ gene lists which have not been described in SS before. Further functional studies, including proteomic analysis, are therefore necessary to elucidate the oncogenic role of these genes in the initiation and progression of SS and other types of CTCL.

\section{Acknowledgments}

This work was supported by British Society for Haematology, Elimination of Leukaemia Fund and Peel Medical Research Trust.

\section{References}

[1] M. Lutzner, R. Edelson, P. Schein, I. Green, C. Kirkpatrick, and A. Ahmed, "Cutaneous T cell lymphomas: the Sezary syndrome, mycosis fungoides, and related disorders," Annals of Internal Medicine, vol. 83, no. 4, pp. 534-552, 1975.

[2] R. Willemze, E. S. Jaffe, G. Burg et al., "WHO-EORTC classification for cutaneous lymphomas," Blood, vol. 105, no. 10, pp. 3768-3785, 2005.

[3] L. M. Weiss, E. Hu, G. S. Wood et al., "Clonal rearrangements of T-cell receptor genes in mycosis fungoides and dermatopathic lymphadenopathy," New England Journal of Medicine, vol. 313, no. 9, pp. 539-544, 1985.
[4] S. J. Whittaker, N. P. Smith, R. R. Jones, and L. Luzzatto, "Analysis of $\beta, \gamma$, and $\delta$ T-cell receptor genes in mycosis fungoides and Sezary syndrome," Cancer, vol. 68, no. 7, pp. 15721582, 1991.

[5] R. Willemze, H. Kerl, W. Sterry et al., "EORTC classification for primary cutaneous lymphomas: a proposal from the cutaneous lymphoma study group of the European organization for research and treatment of cancer," Blood, vol. 90, no. 1, pp. 354-371, 1997.

[6] M. Thangavelu, W. G. Finn, K. K. Yelavarthi et al., "Recurring structural chromosome abnormalities in peripheral blood lymphocytes of patients with mycosis fungoides/sezary syndrome," Blood, vol. 89, no. 9, pp. 3371-3377, 1997.

[7] L. Karenko, E. Hyytinen, S. Sarna, and A. Ranki, "Chromosomal abnormalities in cutaneous T-cell lymphoma and in its premalignant conditions as detected by G-banding and interphase cytogenetic methods," Journal of Investigative Dermatology, vol. 108, no. 1, pp. 22-29, 1997.

[8] L. Karenko, M. Kahkonen, E. E. Hyytinen, M. Lindlof, and A. Ranki, "Notable losses at specific regions of chromosomes $10 \mathrm{q}$ and $13 \mathrm{q}$ in the Sezary syndrome detected by comparative genomic hybridization," Journal of Investigative Dermatology, vol. 112, no. 3, pp. 392-395, 1999.

[9] X. Mao, D. Lillington, J. J. Scarisbrick et al., "Molecular cytogenetic analysis of cutaneous T-cell lymphomas: identification of common genetic alterations in Sézary syndrome and mycosis fungoides," British Journal of Dermatology, vol. 147, no. 3, pp. 464-475, 2002.

[10] X. Mao, D. Lillington, B. Czepulkowski, R. Russell-Jones, B. Young, and S. Whittaker, "Molecular cytogenetic characterisation of Sezary syndrome," Genes Chromosomes Cancer, vol. 36, pp. 250-260, 2003.

[11] X. Mao, G. Orchard, D. M. Lillington, R. Russell-Jones, B. D. Young, and S. J. Whittaker, "Amplification and overexpression of JUNB is associated with primary cutaneous T-cell lymphomas," Blood, vol. 101, no. 4, pp. 1513-1519, 2003.

[12] T. C. Fischer, S. Gellrich, J. M. Muche et al., "Genomic aberrations and survival in cutaneous T cell lymphomas," Journal of Investigative Dermatology, vol. 122, no. 3, pp. 579-586, 2004.

[13] D. A. S. Batista, E. C. Vonderheid, A. Hawkins et al., "Multicolor fluorescence in situ hybridization (SKY) in mycosis fungoides and Sézary syndrome: search for recurrent chromosome abnormalities," Genes Chromosomes and Cancer, vol. 45, no. 4, pp. 383-391, 2006.

[14] M. H. Vermeer, R. Van Doorn, R. Dijkman et al., "Novel and highly recurrent chromosomal alterations in Sézary syndrome," Cancer Research, vol. 68, no. 8, pp. 2689-2698, 2008.

[15] J. J. Scarisbrick, A. J. Woolford, R. Russell-Jones, and S. J. Whittaker, "Loss of heterozygosity on $10 \mathrm{q}$ and microsatellite instability in advanced stages of primary cutaneous T-cell lymphoma and possible association with homozygous deletion of PTEN," Blood, vol. 95, no. 9, pp. 2937-2942, 2000.

[16] J. J. Scarisbrick, A. J. Woolford, R. Russell-Jones, and S. J. Whittaker, "Allelotyping in mycosis fungoides and Sézary syndrome: common regions of allelic loss identified on 9p, 10q, and 17p," Journal of Investigative Dermatology, vol. 117, no. 3, pp. 663-670, 2001.

[17] J. J. Scarisbrick, A. J. Woolford, E. Calonje et al., "Frequent abnormalities of the P15 and P16 genes in mycosis fungoides and Sezary syndrome," Journal of Investigative Dermatology, vol. 118, no. 3, pp. 493-499, 2002. 
[18] X. Mao, Molecular cytogenetics of primary cutaneous lymphomas, Ph.D. thesis, 2004.

[19] E. M. Wain, T. J. Mitchell, R. Russell-Jones, and S. J. Whittaker, "Fine mapping of chromosome $10 \mathrm{q}$ deletions in mycosis fungoides and Sezary syndrome: identification of two discrete regions of deletion at 10q23.33-24.1 and 10q24.33-25.1," Genes Chromosomes and Cancer, vol. 42, no. 2, pp. 184-192, 2005.

[20] L. Tracey, R. Villuendas, P. Ortiz et al., "Identification of genes involved in resistance to interferon- $\alpha$ in cutaneous T-cell lymphoma," American Journal of Pathology, vol. 161, no. 5, pp. 1825-1837, 2002.

[21] L. Tracey, R. Villuendas, A. M. Dotor et al., "Mycosis fungoides shows concurrent deregulation of multiple genes involved in the TNF signaling pathway: an expression profile study," Blood, vol. 102, no. 3, pp. 1042-1050, 2003.

[22] L. Kari, A. Loboda, M. Nebozhyn et al., "Classification and prediction of survival in patients with the leukemic phase of cutaneous T cell lymphoma," Journal of Experimental Medicine, vol. 197, no. 11, pp. 1477-1488, 2003.

[23] X. Mao, G. Orchard, D. M. Lillington et al., "BCL2 and JUNB abnormalities in primary cutaneous lymphomas," British Journal of Dermatology, vol. 151, no. 3, pp. 546-556, 2004.

[24] X. Mao, G. Orchard, T. J. Mitchell et al., "A genomic and expression study of AP-1 in primary cutaneous T-cell lymphoma: evidence for dysregulated expression of JUNB and JUND in MF and SS," Journal of Cutaneous Pathology, vol. 35, no. 10, pp. 899-910, 2008.

[25] R. van Doorn, R. Dijkman, M. H. Vermeer et al., "Aberrant expression of the tyrosine kinase receptor EphA4 and the transcription factor twist in Sézary syndrome identified by gene expression analysis," Cancer Research, vol. 64, no. 16, pp. 5578-5586, 2004.

[26] S. Hahtola, S. Tuomela, L. Elo et al., "Th1 response and cytotoxicity genes are down-regulated in cutaneous T-cell lymphoma," Clinical Cancer Research, vol. 12, no. 16, pp. 4812-4821, 2006.

[27] J. J. Scarisbrick, T. J. Mitchell, E. Calonje, G. Orchard, R. Russell-Jones, and S. J. Whittaker, "Microsatellite Instability Is Associated with Hypermethylation of the hMLH1 Gene and Reduced Gene Expression in Mycosis Fungoides," Journal of Investigative Dermatology, vol. 121, no. 4, pp. 894-901, 2003.

[28] R. van Doorn, W. H. Zoutman, R. Dijkman et al., "Epigenetic profiling of cutaneous T-cell lymphoma: promoter hypermethylation of multiple tumor suppressor genes including BCL7a, PTPRG, and p73," Journal of Clinical Oncology, vol. 23, no. 17, pp. 3886-3896, 2005.

[29] J. G. Hacia, W. Makalowski, K. Edgemon et al., "Evolutionary sequence comparisons using high-density oligonucleotide arrays," Nature Genetics, vol. 18, no. 2, pp. 155-158, 1998.

[30] D. G. Wang, J. B. Fan, C. J. Siao et al., "Large-scale identification, mapping, and genotyping of single- nucleotide polymorphisms in the human genome," Science, vol. 280, no. 5366, pp. 1077-1082, 1998.

[31] H. Matsuzaki, H. Loi, S. Dong et al., "Parallel genotyping of over 10,000 SNPs using a one-primer assay on a high-density oligonucleotide array," Genome Research, vol. 14, no. 3, pp. 414-425, 2004.

[32] S. John, N. Shephard, G. Liu et al., "Whole-genome scan, in a complex disease, using 11,245 single-nucleotide polymorphisms: comparison with microsatellites," American Journal of Human Genetics, vol. 75, no. 1, pp. 54-64, 2004.

[33] D. J. Schaid, J. C. Guenther, G. B. Christensen et al., "Comparison of microsatellites versus single-nucleotide polymorphisms in a genome linkage screen for prostate cancer-susceptibility loci," American Journal of Human Genetics, vol. 75, no. 6, pp. 948-965, 2004.

[34] X. Zhou, S. C. Mok, Z. Chen, Y. Li, and D. T. W. Wong, "Concurrent analysis of loss of heterozygosity (LOH) and copy number abnormality (CNA) for oral premalignancy progression using the Affymetrix 10K SNP mapping array," Human Genetics, vol. 115, no. 4, pp. 327-330, 2004.

[35] M. T. Teh, D. Blaydon, T. Chaplin et al., "Genomewide single nucleotide polymorphism microarray mapping in basal cell carcinomas unveils uniparental disomy as a key somatic event," Cancer Research, vol. 65, no. 19, pp. 8597-8603, 2005.

[36] M. Gaasenbeek, K. Howarth, A. J. Rowan et al., "Combined array-comparative genomic hybridization and singlenucleotide polymorphism-loss of heterozygosity analysis reveals complex changes and multiple forms of chromosomal instability in colorectal cancers," Cancer Research, vol. 66, no. 7, pp. 3471-3479, 2006.

[37] A. Dutt and R. Beroukhim, "Single nucleotide polymorphism array analysis of cancer," Current Opinion in Oncology, vol. 19, no. 1, pp. 43-49, 2007.

[38] J. N. Kloth, J. Oosting, T. van Wezel et al., "Combined arraycomparative genomic hybridization and single-nucleotide polymorphism-loss of heterozygosity analysis reveals complex genetic alterations in cervical cancer," BMC Genomics, vol. 8, article 53, 2007.

[39] M. Łastowska, V. Viprey, M. Santibanez-Koref et al., "Identification of candidate genes involved in neuroblastoma progression by combining genomic and expression microarrays with survival data," Oncogene, vol. 26, no. 53, pp. 7432-7444, 2007.

[40] D. F. Levinson, O. V. Evgrafov, J. A. Knowles et al., "Genetics of recurrent early-onset major depression (GenRED): significant linkage on chromosome 15q25-q26 after fine mapping with single nucleotide polymorphism markers," American Journal of Psychiatry, vol. 164, no. 2, pp. 259-264, 2007.

[41] K. J. Purdie, S. R. Lambert, M. T. Teh et al., "Allelic imbalances and microdeletions affecting the PTPRD gene in cutaneous squamous cell carcinomas detected using single nucleotide polymorphism microarray analysis," Genes Chromosomes and Cancer, vol. 46, no. 7, pp. 661-669, 2007.

[42] M. Raghavan, L. L. Smith, D. M. Lillington et al., "Segmental uniparental disomy is a commonly acquired genetic event in relapsed acute myeloid leukemia," Blood, vol. 112, no. 3, pp. 814-821, 2008.

[43] G. C. Kennedy, H. Matsuzaki, S. Dong et al., "Large-scale genotyping of complex DNA," Nature Biotechnology, vol. 21, no. 10, pp. 1233-1237, 2003.

[44] M. Gupta, M. Raghavan, R. E. Gale et al., "Novel regions of acquired uniparental disomy discovered in acute myeloid leukemia," Genes Chromosomes and Cancer, vol. 47, no. 9, pp. 729-739, 2008.

[45] G. Schwarz, S. Bäumler, A. Block, F. G. Felsenstein, and G. Wenzel, "Determination of detection and quantification limits for SNP allele frequency estimation in DNA pools using real time PCR," Nucleic Acids Research, vol. 32, no. 3, article e24, 2004.

[46] X. Mao and S. McElwaine, "Functional copy number changes in Sézary syndrome: toward an integrated molecular cytogenetic map III," Cancer Genetics and Cytogenetics, vol. 185, no. 2, pp. 86-94, 2008.

[47] X. Mao, R. A. Hamoudi, I. C. Talbot, and M. Baudis, "Allelespecific loss of heterozygosity in multiple colorectal adenomas: toward an integrated molecular cytogenetic map II," Cancer Genetics and Cytogenetics, vol. 167, no. 1, pp. 1-14, 2006. 
[48] S. Hahtola, E. Burghart, M. Puputti et al., "Cutaneous T-cell lymphoma-associated lung cancers show chromosomal aberrations differing from primary lung cancer," Genes Chromosomes and Cancer, vol. 47, no. 2, pp. 107-117, 2008.

[49] C. Querfeld, S. T. Rosen, J. Guitart, and T. M. Kuzel, "The spectrum of cutaneous T-cell lymphomas: new insights into biology and therapy," Current Opinion in Hematology, vol. 12, no. 4, pp. 273-278, 2005.

[50] X. Mao, R. Barfoot, R. A. Hamoudi, and M. Noble, "Alleletyping of an oligodendrocyte-type-2 astrocyte lineage derive from a human glioblastoma multiforme," Journal of NeuroOncology, vol. 40, no. 3, pp. 243-250, 1998.

[51] X. Mao, R. Barfoot, R. A. Hamoudi, D. F. Easton, A. M. Flanagan, and M. R. Stratton, "Allelotype of uterine leiomyomas," Cancer Genetics and Cytogenetics, vol. 114, no. 2, pp. 89-95, 1999.

[52] X. Mao, R. A. Hamoudi, P. Zhao, and M. Baudis, "Genetic losses in breast cancer: toward an integrated molecular cytogenetic map," Cancer Genetics and Cytogenetics, vol. 160, no. 2, pp. 141-151, 2005.

[53] K. Nakaya, H. D. Yamagata, N. Arita et al., "Identification of homozygous deletions of tumor suppressor gene FAT in oral cancer using CGH-array," Oncogene, vol. 26, no. 36, pp. 53005308, 2007.

[54] K. Chosdol, A. Misra, S. Puri et al., "Frequent loss of heterozygosity and altered expression of the candidate tumor suppressor gene 'FAT' in human astrocytic tumors," BMC Cancer, vol. 9, article 5, 2009.

[55] J. S. Beckmann, X. Estivill, and S. E. Antonarakis, "Copy number variants and genetic traits: closer to the resolution of phenotypic to genotypic variability," Nature Reviews Genetics, vol. 8, no. 8, pp. 639-646, 2007.

[56] S. A. McCarroll and D. M. Altshuler, "Copy-number variation and association studies of human disease," Nature Genetics, vol. 39, no. 1, supplement 7, pp. S37-S42, 2007.

[57] H. H. Ropers, "New perspectives for the elucidation of genetic disorders," American Journal of Human Genetics, vol. 81, no. 2, pp. 199-207, 2007. 

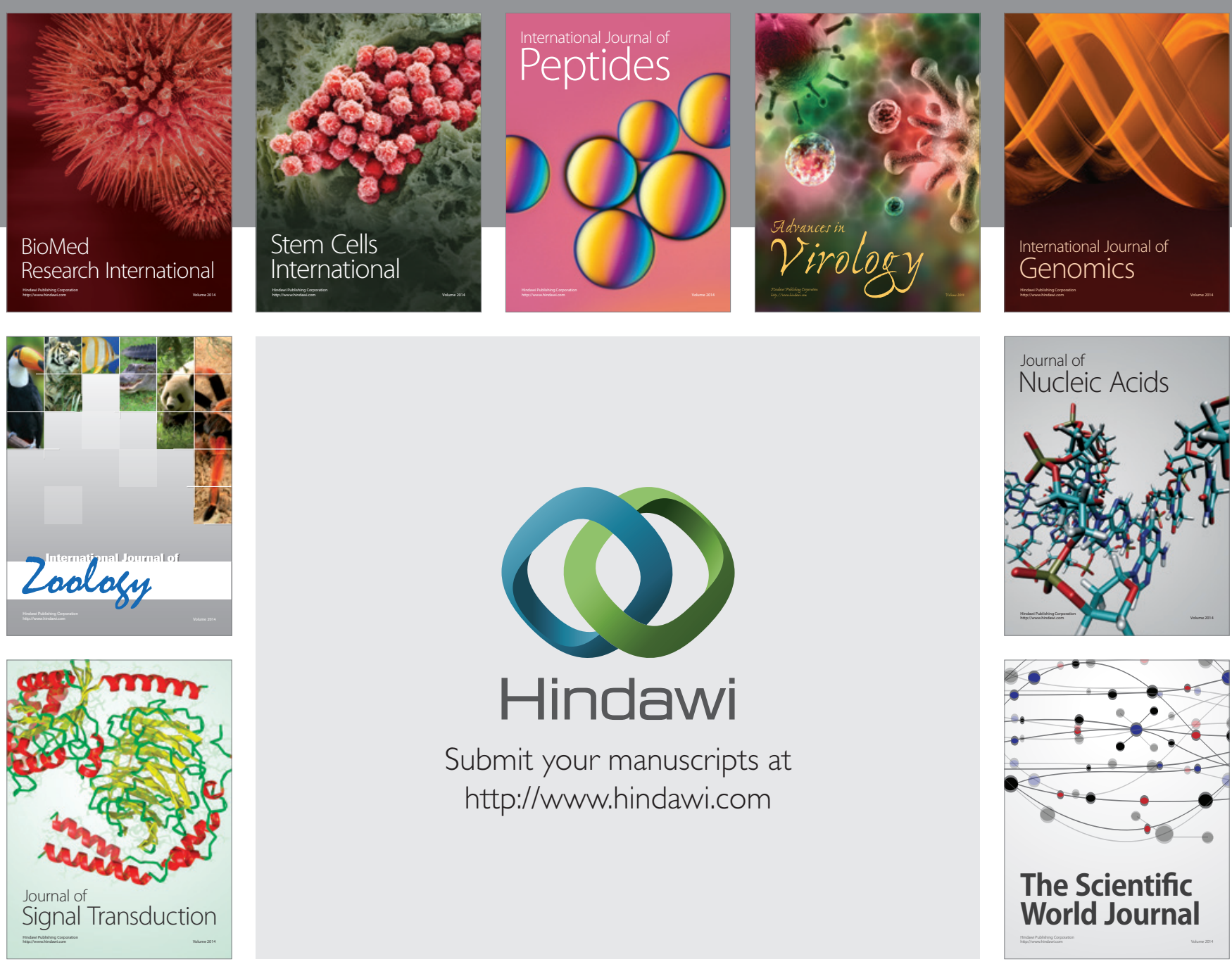

Submit your manuscripts at

http://www.hindawi.com
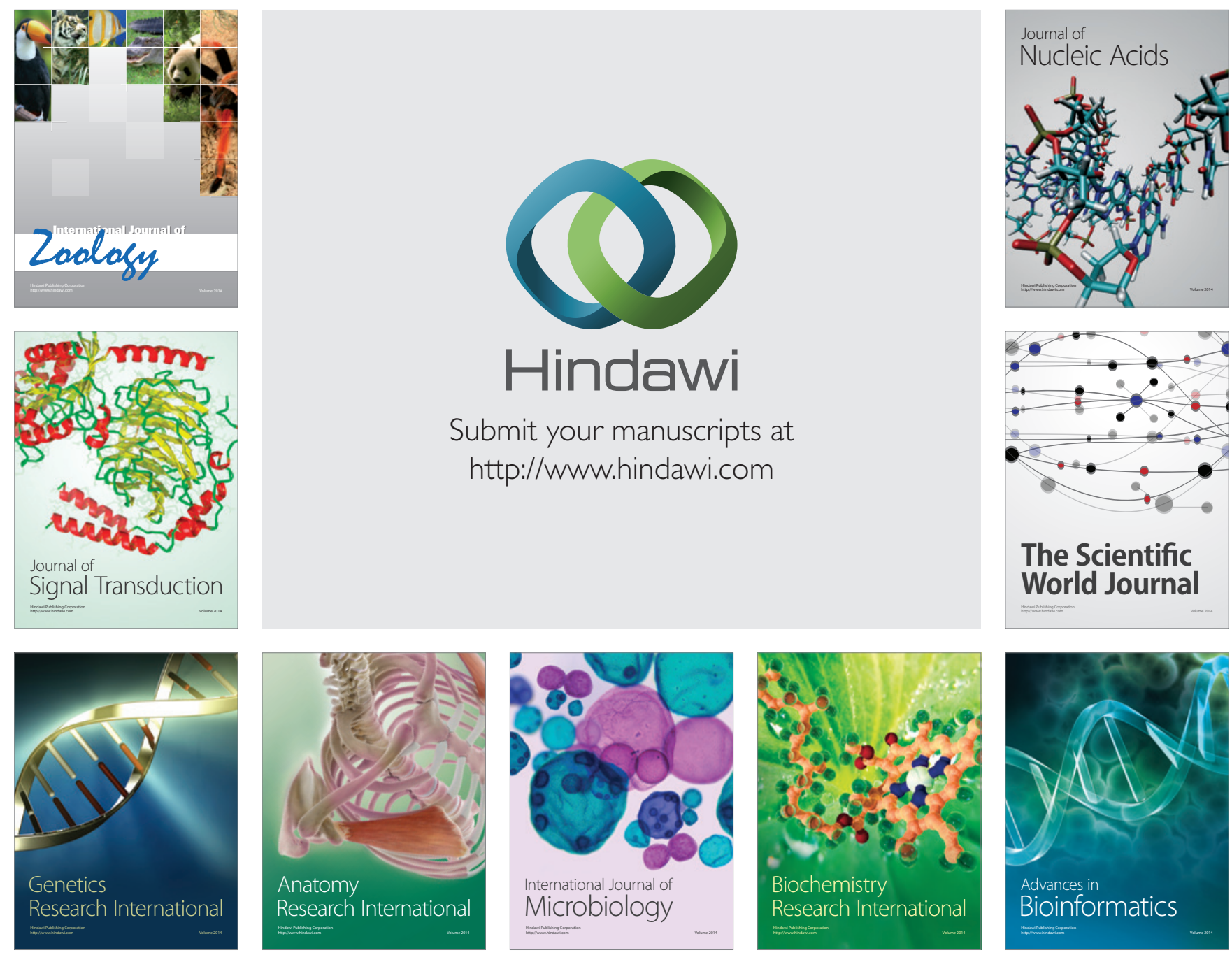

The Scientific World Journal
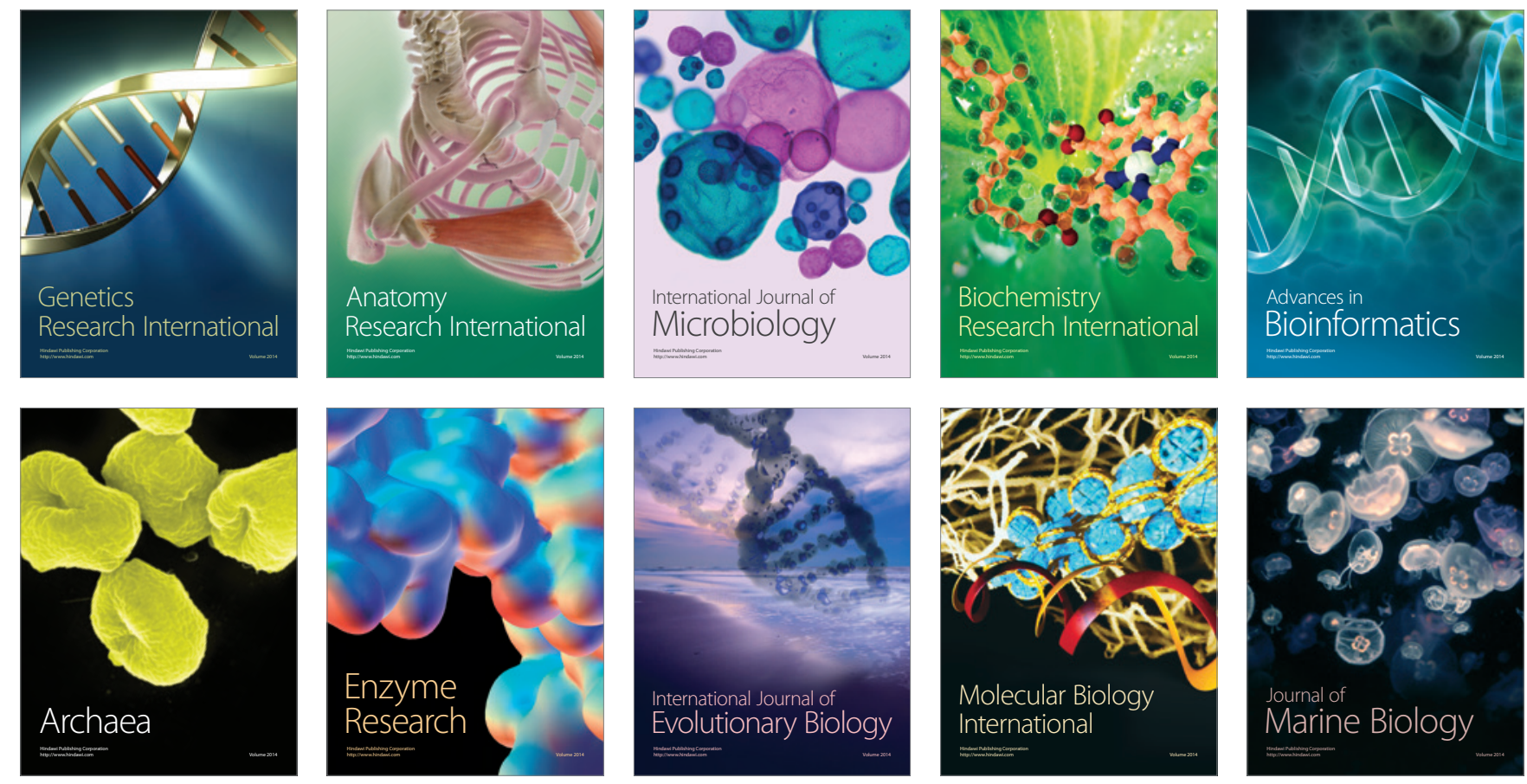